\title{
Education on Increasing Sales of Agricultural Products with Social Media at the Sabilulungan Women Farmers Demplot Group in Sumedang
}

\author{
Deden Rudiansyah \\ Department of Agrotechnology, Universitas Garut, Garut, Indonesia
}

Corresponding author email: dedenrudiansyah@gmail.com

\begin{abstract}
Community Service is one of the Tri Dharma of Higher Education, especially at Garut University, it is hoped that with this community service the existence of universities can contribute to the development of scientific application to the community. In the current era of technology, which requires all small industry players to improve their abilities in the field of communication and information technology, currently internet-based technology creates a business environment that is no longer concerned with time and distance. The implementation of sales education through social media is a service to the community with the aim of helping the Sabilulungan Women's Farmers' Demplot Group to increase sales and income so that the Demplot Farmers' Group can survive in today's business competition. The activity method in community service uses a technique of delivering material verbally to the participants, this community service has a background problem because agricultural products from the Demonstration Farmer Group still sell conventional products and have not made good use of online sales using social media and e-commerce platforms. The results of the research carried out were able to innovate marketing which was originally conventional into marketing that utilizes technological developments, namely by conducting electronic marketing by utilizing social media and E-commerce platforms as sales media.
\end{abstract}

Keywords: Education, Farmers, Agribusiness, Information Technology

\section{Introduction}

The low level of education, almost all informal workers in agriculture in Indonesia in particular and developing countries in general, as well as in India there are still many illiterate farmers. The low level of education causes the low ability of farmers in terms of utilizing technology that can hamper economic growth for farmers (Sam et al., 2007; Aditantri et al., 2021; Ula et al., 2021). Agricultural technology in the field of agriculture has been found so that it produces agricultural products that are in abundance. However, if the sales management system is not updated, it will become stagnant so that the economy does not improve. Indonesian farmers must be responsive to the pace of technological development. All technologies can be learned, including those studied by Indonesian farmers (Reddy and Ankaiah, 2005; Inopianti et al., 2021).

Utilization of these technological developments to support agricultural business systems. In addition to seeking information about agricultural cultivation, it can also be used as a means of communicating with other farmers or stakeholders who are far away to carry out the marketing function of agricultural products. Agricultural products that are not durable and easily damaged require a separate marketing method, to be able to go directly into the hands of consumers (Cox, 2002; Suma et al., 2017). Material regarding the description of information technology in the form of e-commerce that can integrate with social media is also very much needed because it makes people more aware to continue to develop themselves in terms of science and information (Rubiani et al., 2020; Patel and Kale, 2016). Along with the development of Information Technology in the current 4.0 revolution era, it is possible to take seriously the exploration of the potential of human resources both at the level of entrepreneurial independence, thus demanding technology to be able to follow the level of community needs for the problems that have occurred so far (Setiawan and Putri, 2020; Chandra et al., 2018).

Sumedang Regency is one of the regencies in West Java Province. Based on Regional Regulation Number 2 of 2012 concerning Spatial Planning for Sumedang Regency in 2011 - 2013; BPMPD 2016 Geographically, the administrative area of Sumedang Regency is directly adjacent to the administrative area of Indramayu Regency in the north, Garut Regency and Bandung Regency in the south, West Bandung Regency and Subang Regency in the west 
and Majalengka Regency in the east. Based on KSA data conducted by BPS for rice production in Sumedang Regency in 2020 for hoticulture crops for vegetable types, the largest production amount was Cabbage of 82,117 quintals, with production centers in Tanjungsari, Sukasari, Cimanggung, Rancakalong and Pamulihan sub-districts (Badan Pusat Statistik Kabupaten Sumedang 2021). Production Results of Crops and Vegetables and Fruits in Seasons in Semarang Regency in 2019-2020 will be presented in Table 1.

Tabel 1. Vegetable Production Results in Seasons in Sumedang Regency in 2019-2020

\begin{tabular}{lcc}
\hline \multicolumn{1}{c}{ Description } & \multicolumn{2}{c}{ Per Quarter } \\
& $\mathbf{2 0 1 9}$ & $\mathbf{2 0 2 0}$ \\
\hline Cabbage & 73.603 & 82.117 \\
Big Chili & 50.348 & 69.071 \\
Cucumber & 39.804 & 51.032 \\
Cayanne Pepper & 33.241 & 43.338 \\
Red Beans & 32.006 & 10.239 \\
Tomato & 30.718 & 37.174 \\
\hline
\end{tabular}

Source: Badan Pusat Statistik Sumedang

Based on Table 1, it can be seen that cabbage is the main agricultural commodity in Sumedang Regency with a significant increase in 2020, with production centers located in Tanjungsari, Sukasari, Rancakalong, and Pamulihan sub-districts. In Rancakalong District there is a farmer group that will be the object of this community service, namely the Sabilulungan Women's Farmer Demonstration Group with the main commodity in agriculture, namely cabbage.

Agriculture is one of the leading commodities in Indonesia, this is evidenced by where the Indonesian government relies on the agricultural sector to boost gross domestic product (GDP) in 2020, the high demand makes the agricultural sector have a vital role in efforts to improve the Indonesian economy during the COVID-19 pandemic. But on the other hand, sometimes many community groups do not benefit due to the problems that arise because the marketing of these agricultural products is quite minimal so that their products are rarely known by the wider community (Gray, 2020).

For this reason, it is necessary to empower farmers with a cooperative farming model to reduce the marketing chain (Islam et al., 2020). In this case, the community must also be able to follow the rhythm of the times where the era of modernization is developing very rapidly, especially in terms of information technology so that people must have sufficient knowledge and insight to coexist with an all-electronic era like today.

Based on research conducted by Saridakis et al. (2017) mentioned that the increase in performance was not significantly different among SMEs that were at the E-commerce development stage. In summary, business performance appears to improve as entrepreneurial organizations adopt information technology to facilitate greater market communication and increased exposure to online shoppers. Then the research was carried out by Purba et al. (2021), the research shows that digital marketing has a significant effect on business continuity, then e-commerce has a significant effect on business continuity and digital marketing has a significant effect on financial performance. The farmers have the right to benefit from technological advances, this is like farmers in Negeria, to advance agriculture technologies that are often used by farmers include radio, television, video and audio players as well as telephones (Lawal-Adebowale and Akeredolu-Ale, 2010).

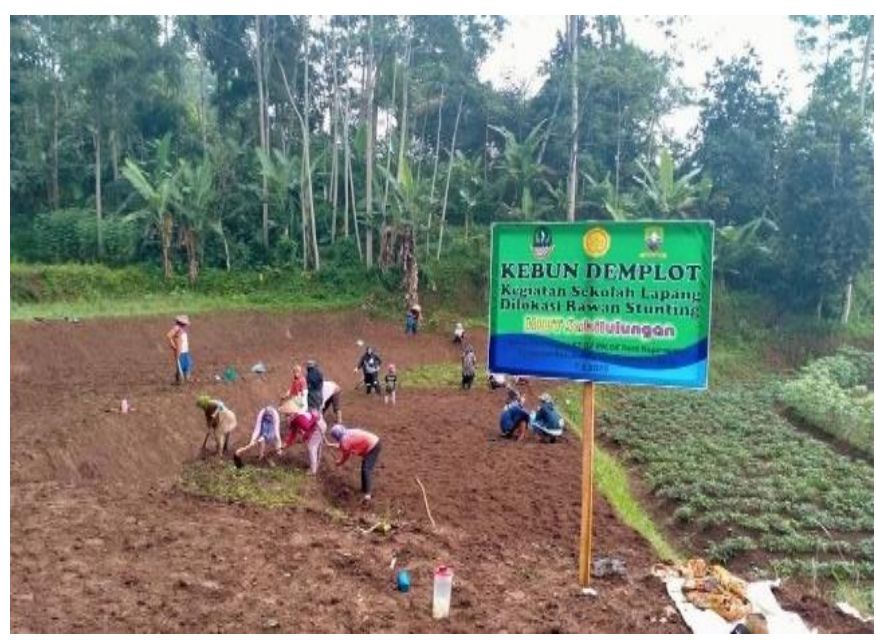

Figure 1 Sabilulungan Demplot Farmer Women's Group 
The purpose of this community service is to help the Sabilulungan Women Farmers Group in increasing marketing broadly by utilizing social media and e-commerce platforms. Some of the things the team did in this service activity were providing education about understanding digital marketing-based marketing methods by utilizing social media and e-commerce platforms and then providing assistance to the Women Farmers Group in packaging products and providing simple trademarks so that consumers could knowing and differentiating products from the Sabilulungan Demplot Women Farmer Group with products from other farmer groups (See Figure 1).

\section{Methodology}

The implementation of the service activity will take place on December 24, 2021 at Nagarawangi, Rancakalong, Sumedang Regency, West Java 45361. The map location sabilulungan demplot farmer women's group can be seen in Figure 2.

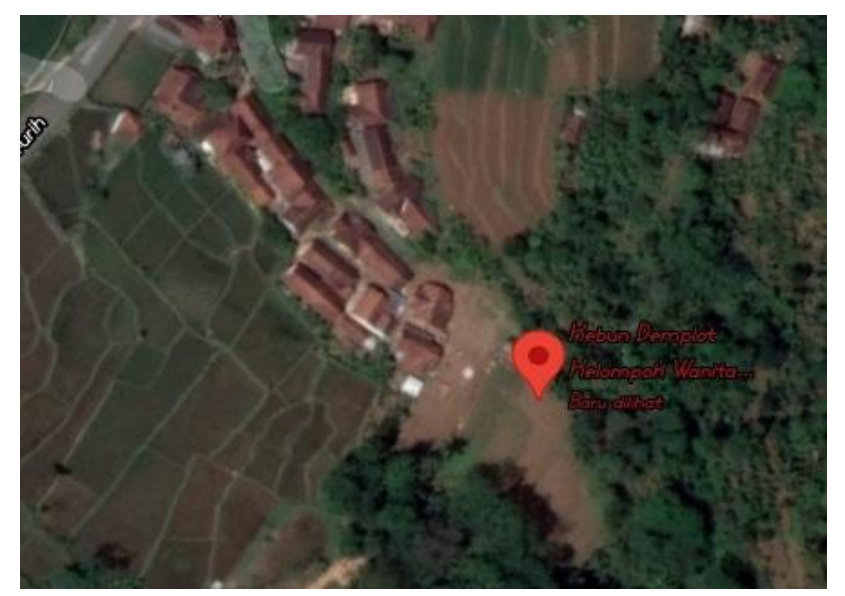

Figure 2 Map Location Sabilulungan Demplot Farmer Women's Group

The methods used in the implementation of community service activities are field analysis, socialization of activities, and implementation stage which includes:

- Field Analysis

This activity was carried out as the beginning of the activity with the aim of obtaining a description of the condition of the targeted UKM by holding a meeting and asking for permission to conduct education for the Sabilulungan Women Farmers Group with one member, Mrs. Ani Rismayanti.

- Socialization of Activities

In this stage, the service team will provide and explain the service plan that will be carried out so that time and various technical needs can be arranged in connection with the overall implementation of the training to the Sabilulungan Women Farmers Group.

- Implementation Stage

Education about increasing sales using social media at the Sabilulungan Women's Farmers' Group by helping members of the Sabilulungan Women's Farmers' Group in understanding some of the facilities and benefits that can be used as a product marketing tool and then given ways for partners to have social media accounts such as Facebook, Instagram , as well as TikTok and can operate E-commerce in the Tokopedia, Bukalapak, Lazzada and Shopee applications. Furthermore, it provides an explanation of the importance of a brand in products and how to package agricultural products in order to attract buying interest from potential consumers, so that the resulting products can compete with products in national and international market shares.

\section{Results And Discussion}

This community service activity was carried out in Nagarawangi, Rancakalong, Sumedang Regency, West Java 45361. This training method aims to provide knowledge about marketing by utilizing social media and e-commerce platforms so that the marketing area for agricultural products becomes wider, Implementation of counseling This is fully supported by the members and the chairperson of the Sabilulungan Women Farmers Group by giving permission to organize sales increase education using social media (See Figure 3). 


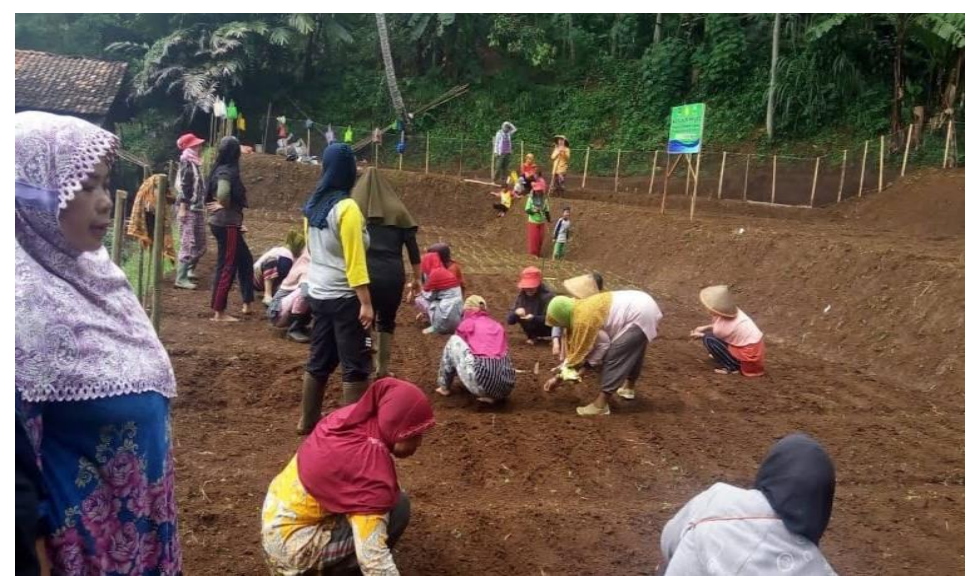

Figure 3 The Process of Planting Plants in the Sabilulungan Demplot Farmer's Group

This service will provide several activities to overcome the problems that exist in the Sabilulungan Women Farmers Group by providing education on how to obtain and create a simple brand of agricultural products, determine packaging that makes the product durable and attract consumer interest, obtain media social media to do marketing and understand it, and get accounts in e-commerce applications and understand it.

This training was given with the aim of opening the insight of the chairman and members of the Sabilulungan Women's Farmers Group that every good product cannot be separated from giving a good brand to the product produced, and no less important that the resulting product must be packaged in an attractive, good and safe manner. This is done so that the goods produced are not easily damaged even though they are packaged. In addition to the training mentioned above, the program team provides marketing training based on digital marketing by utilizing social media and e-commerce platforms where this training aims to introduce and at the same time train the Sabilulungan Women Farmers Group to use digital marketing in marketing their products (See Figure 4).

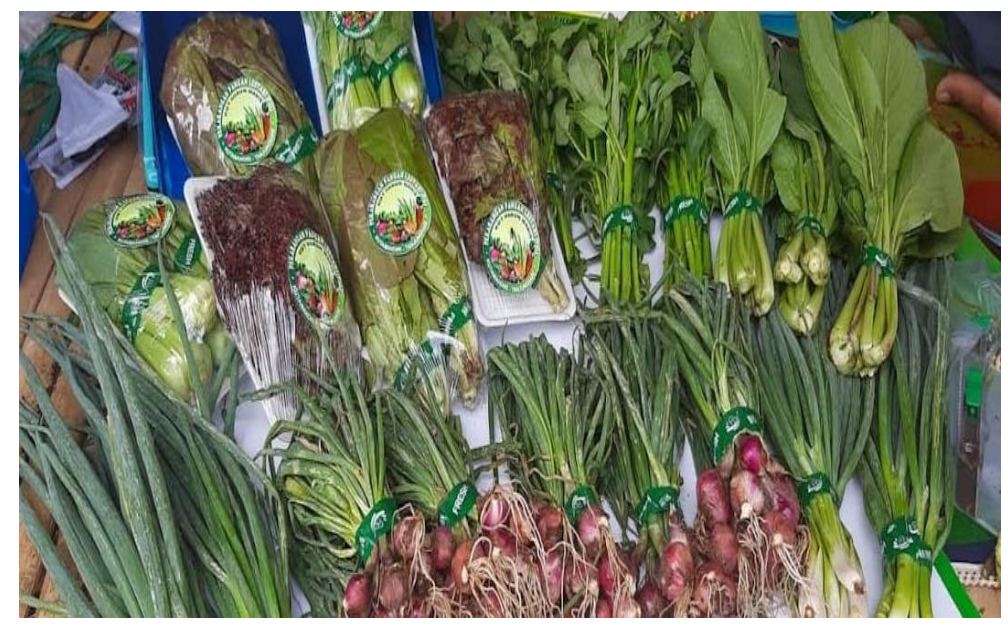

Figure 4 Branding and Packaging of Agricultural Products for the Sabilulungan Women's Farmer's Demplot Group

The last training is training related to creating and understanding account functions from e-commerce applications such as Lazada, Tokopedia, Shopee and product marketing using social media such as Instagram, Facebook, and TikTok. As we all know, although technology has many negative impacts, there are also many benefits that can be taken from technological developments, one of which is that it can be used as a means of promotion that does not drain the finances of a business, especially small industrial businesses or home industries. This training teaches the Demonstration Women Farmers Group how the Demonstration Women Farmers Group can register and obtain an account on an e-commerce application on an online application.

This service does not only provide training but also provides assistance to the Sabilulungan Women Farmers Group so that later it can strengthen business competition at this time. The Sabilulungan Demplot Women Farmers Group was assisted in marketing products on e-commerce applications, this was done because the Sabilulungan Demplot Women Farmers Group felt the need to be given assistance in the operation of e-commerce marketing. This assistance is also given to the members and the chairperson of the group. 
With the implementation of this community service program, the Sabilulungan Women Farmers Group was able to resolve what had been the problem so far, the chairman and members of the Sabilulungan Demplot Women Farmers Group plot now have a simple brand that will not be followed by other industries, and this can lead to provide protection for businesses owned by the Women Farmers Group. In addition, the Women Farmers Group now has good and attractive packaging so that it has an attraction for new consumers and can overcome marketing problems that previously conventionally have now marketed their products by utilizing online-based social media and ecommerce applications, this is a new tool for the Women's Group. Farmers to promote to the general public and wide, not limited by distance and time in selling agricultural products from the Sabilulungan Demonstration Farmer Women's Group.

\section{Conclussion}

Based on the results obtained from this training program, it can increase the knowledge and skills of the Sabilulungan Women's Farmer Group. This can be seen from the problems faced by the Women Farmers Group related to unbranded products, poor packaging, and still doing conventional marketing. By doing this service, the problems of the Women Farmers Group are solved by having a simple brand, having attractive and safe packaging which makes the Women Farmers Group's products more highly selling power, furthermore, marketing that used to be conventional has now used social media and e-commerce in marketing the products that have been produced has a positive impact on product sales turnover.

\section{Acknowledgments}

We hope that with this community service, we can apply it continuously so that the profit from product sales is maximally obtained by the owners of the Sabilulungan Women Farmers Group

\section{References}

Aditantri, R., Mahliza, F., \& Wibisono, A. D. (2021). Urban Planning and E-Commerce: Understanding the Impact During Pandemic Covid-19 in Jakarta. International Journal of Business, Economics, and Social Development, 2(3), $135-142$.

Badan Pusat Statistik Kabupaten Sumedang. 2021. Statistik Daerah Kabupaten Sumedang 2021. Sumedang: Badan Pusat Statistik Kabupaten Sumedang.

Chandra, A., McNamara, K. E., \& Dargusch, P. (2018). Climate-smart agriculture: perspectives and framings. Climate Policy, 18(4), 526-541.

Cox, S. (2002). Information technology: the global key to precision agriculture and sustainability. Computers and electronics in agriculture, 36(2-3), 93-111.

Gray, R. S. (2020). Agriculture, transportation, and the COVID-19 crisis. Canadian Journal of Agricultural Economics/Revue canadienne d'agroeconomie, 68(2), 239-243.

Islam, M., Jannat, A., Al Rafi, D. A., \& Aruga, K. (2020). Potential Economic Impacts of the COVID-19 Pandemic on South Asian Economies: A Review. World, 1(3), 283-299.

Inopianti, N., Munibah, K., \& Purwanto, M. Y. J. (2021). Implementation of Sustainable Food Agricultural Land Protection Policy in Sukabumi City, West Java, Indonesia. International Journal of Business, Economics, and Social Development, 2(3), 107-112.

Lawal-Adebowale, O. A., \& Akeredolu-Ale, B. I. (2010). Agricultural workers' perception of information and communication technology usage for agricultural development in Southwest Nigeria. Journal of Social Development in Africa, $25(2), 147$.

Patil, K. A., \& Kale, N. R. (2016, December). A model for smart agriculture using IoT. In 2016 International Conference on Global Trends in Signal Processing, Information Computing and Communication (ICGTSPICC) (pp. 543-545). IEEE.

Purba, M., Simanjutak, D., Malau, Y., Sholihat, W., \& Ahmadi, E. (2021). The effect of digital marketing and e-commerce on financial performance and business sustaina-bility of MSMEs during COVID-19 pandemic in Indonesia. International Journal of Data and Network Science, 5(3), 275-282.

Reddy, P. K., \& Ankaiah, R. (2005). A framework of information technology-based agriculture information dissemination system to improve crop productivity. Current Science, 88(12), 1905-1913. 
Rubiani, H., Samsoleh, E., Fitri, S., Taufiq, M., \& BAG, N. L. (2020). Sosialisasi Sistem Informasi Kebencanaan Untuk Smp Dan Sma Di Kabupaten Pangandaran. Monsu'ani Tano Jurnal Pengabdian Masyarakat, 3(1), 26-31

Sam, K. G., Andrade, H. H., Pradhan, L., Pradhan, A., Sones, S. J., Rao, P. G., \& Sudhakar, C. (2008). Effectiveness of an educational program to promote pesticide safety among pesticide handlers of South India. International archives of occupational and environmental health, 81(6), 787-795.

Saridakis, G., Lai, Y., Mohammed, A. M., \& Hansen, J. M. (2018). Industry characteristics, stages of E-commerce communications, and entrepreneurs and SMEs revenue growth. Technological Forecasting and Social Change, 128, 56-66.

Setiawan, I. W. A., Putri, P. H., Candra, K. O., Yanti, D., Widhiasthinid, N. W., \& Kurniawane, I. G. A. (2020). Literacy Utilisation of Information Technology for Farmers in Badung Regency, Bali, in the Era of Industrial Revolution 4.0. Literacy, 13(11), 1231-1245.

Suma, N., Samson, S. R., Saranya, S., Shanmugapriya, G., \& Subhashri, R. (2017). IOT based smart agriculture monitoring system. International Journal on Recent and Innovation Trends in computing and communication, 5(2), 177-181.

Ula, S., Eng, M., Susilo, S., Listijorini, E., Irawan, R., Sambas, A., \& Assidiq, A. T. (2021). Spraying Agricultural Crops Based on Internet of Things (IoT). FLYWHEEL: Jurnal Teknik Mesin Untirta, 20-25. 